УДК 330.341 .1

DOI: https://doi.org/10.26642/jen-2019-3(89)-57-65

Г.М. Тарасюк, д.е.н., проф.

А.О. Чагайда, к.т.н., доц.

Державний університет «Житомирська політехніка»

\title{
Перспективи впровадження технології енергетичних батончиків у закладах готельно-ресторанного господарства
}

\begin{abstract}
Сучасний стиль життя людей значно прискорив зміну ринку харчових продуктів, основними вимогами до яких стає загальнодоступність, ивидке отримання достатньої кількості енергї для відновлення фізичних сил та приведення в тонус мозкової діяльності. Для задоволення цих потреб запропоновано виробництво у готельно-ресторанних господарствах енергетичних батончиків, щзо мають високу біологічну цінність та гармонійні органолептичні показники.

Пропонується використовувати як технологію з термічним обробленням рослинної сировини, так $i$ без такого оброблення. За запропонованим рецептурним складом таких батончиків у закладах готельно-ресторанного господарства буде отримано иілком безпечний продукт харчування із більш збалансованим складом основних пожсивих речовин, значною кількістю мікроелементів, вітамінів і біологічно активних речовин антистресової та імуностимулюючоі dii.

Ключові слова: управління закладом готельно-ресторанного господарства; технологія виробництва енергетичних батончиків; рецептурний склад; безпечність харчових продуктів.
\end{abstract}

Постановка проблеми у загальному вигляді та її зв'язок з практичними завданнями. В наш час харчові звички людей змінюються дуже швидко і основним трендом $є$ те, що добавки та барвники стають все більш неприйнятними: споживачі більше не хочуть бачити в складі продуктів слова, які не можуть вимовити. Продукти і напої, які ми споживаємо, є джерелом необхідної кількості поживних речовин, вітамінів, мікро- та макроелементів, необхідних для нормального функціонування організму. Для стимуляції нервової системи використовують енергетичні напої - досить недавній винахід людства, хоча їх інгредієнти вже давно знайшли застосування [1]. До складу більшості подібних напоїв входять вуглеводи, амінокислоти, вітаміни та мінерали, продукти рослинного походження і кофеїн. Вважається, що вуглеводи «заряджають» напої енергією; вітаміни (A, D, B 1 (тіамін), B2 (рибофлавін), В3 (ніацин), В4 (піридоксин)) активізують роботу м'язів; кофеїн, як відомо, бадьорить, а продукти рослинного походження (гуарана, бджолиний пилок, женьшень) також додають енергії. Енергетичні компоненти рослинного походження в технологічних і термодинамічних перетвореннях трансформуються до рівнів більш високого засвоєння з проявами лікувальних наслідків і полегшеною структурою [2, 3]. Важливим традиційним напрямом, що стосується харчових технологій, $є$ механічне подрібнення і механоактивізація сировинних потоків, у тому числі для отримання харчових добавок підвищеної біологічної цінності [4]. Популярність енергетичних напоїв постійно зростає, тому що їх споживання збільшує швидкість реакції, піднімає настрій і підвищує фізичну витривалість $[5,6]$.

Іншим популярним джерелом енергії та вуглеводів стали енергетичні батончики та спеціальне харчування, продажі яких на ринку у Великій Британії за період 32010 до 2015 років потроїлися, досягнувши 137 мільйонів євро, у той час як ринок США подвоївся за той самий період до 2314 мільйонів євро. Для задоволення потреб споживачів у відмінному смаку, текстурі готового виробу та натуральних компонентах, інноваційні компанії використовують альтернативні джерела білків, переглядають початкові рецептури, додають незвичні інгредієнти для отримання нових цікавих продуктів [7].

Аналіз останніх досліджень та публікації. Питання управління технологічними процесами, або «технологічний менеджмент», в українській науковій літературі досліджене недостатньо, хоча в умовах зростання ринкової конкурентної боротьби безумовною необхідністю $є$ впровадження технологічних інновацій у виробництво. Найбільш відомими іноземними дослідженнями, у яких наголошується на важливості управління технологіями та визначається його специфіка, є праці Х.Моріна; В.К. Нараянана; Р.А. Бургелмана, К.М. Крістенсена, С.К. Вілрайта; Х.Кропсу-Вехкапера, Х.Хаапасало, Дж.-П. Русанена. Серед українських дослідників цієї проблематики необхідно виокремити -Н.Т. Рудь, в останні роки молодих українських науковців I.В. Мілько та О.Г. Шевлюгу.

Питаннями дослідження технології виробництва енергетичних батончиків займаються вітчизняні вчені, такі як: Н.В. Притульська, О.О. Мусійчук, І.В. Коваль; М.К. Войтюк; В.Ф. Дрель, Г.І. Сєногонова, Л.І. Сєногонова, О.О. Ємельянова, які запатентували власні корисні моделі, проте жодна 3 них не була впроваджена у виробництво на базі закладів готельно-ресторанного господарства.

Метою статті $є$ дослідження перспектив впровадження технологій енергетичних батончиків у закладах готельно-ресторанного господарства.

(C) Г.М. Тарасюк, А.О. Чагайда, 2019 
Викладення основного матеріалу. Американські споживачі почали уникати багатьох основних продуктів харчування, які раніше домінували в портфелях таких компаній, як General Mills i Hershey. За інформацією Wall Street Journal, зростання продажів шоколаду в США щороку, починаючи з 2010 року, сповільнюється, в той час як продажі зернових з 2009 до 2014 року взагалі впали на 5 \%. За даними Національного інституту маркетингу США, основним показником, який впливає на вибір населення, $є$ вміст білків: у 2006 році 39 \% населення США заявляли, що шукають продукти з високим вмістом білків, а у 2014 році таких вже було $53 \%$. Компанії, від величезних виробників шоколаду до стартапів, що займаються здоровою їжею, вкладають значні кошти в розробку протеїнових закусок: у січні 2016 року компанія General Mills придбала лідера м'ясної промисловості Epic Bar; стартапи (Kratos, Omnibar i Caveman Foods) також дебютували із м'ясними батончиками, які продаються не тільки в спеціалізованих магазинах, але і в мережах великих роздрібних гігантів Whole Foods i Costco. Компанії всієї харчової галузі намагаються скористатись тенденцію із зростанням попиту на продукти з високим вмістом білків, при цьому враховують думку значної частини споживачів, що саме м'ясо є джерелом натурального білка. У серпні 2016 року Hershey запустила продаж батончиків із сушеного м'яса Krave з таким незвичним смаком, як чорнична яловичина на грилі [8]. Для запуску цього продукту Hershey Company на початку 2015 року викупила виробника в'яленого м'яса Krave Pure Foods Inc., який спеціалізувався на виробництві вельми незвичних м'ясних батончиків: зі смаком черешні та барбекю; ананасовим та апельсиновим; цитрусовим та базиліку (на момент поглинання зростання продажів продукції Krave складало більш ніж у два рази за рік). У зв’язку зі скороченням попиту на профільну продукцію капіталізація Hershey’s у 2015 році скоротилася на 14 \%, тому вихід на новий ринок став для компанії вельми перспективним: окрім м'ясних енергетичних батончиків компанія запровадила технологію снеків для вегетаріанців, до складу яких входить мигдаль, насіння соняшника та протеїн [9].

У глобальній стратегії Всесвітної організації охорони здоров'я в галузі безпеки харчових продуктів зазначено, що хімічні речовини $є$ істотним джерелом хвороб харчового походження, адже харчові добавки і поживні елементи (вітаміни і найважливіші мінеральні речовини), залишкові кількості пестицидів і ветеринарних лікарських засобів, що довільно використовуються, з метою розширення або поліпшення системи постачання продовольством, без необхідних доказів їх безпечності [10]. Тому компанія Nestlé USA провела грунтовне дослідження серед споживачів бренда BUTTERFINGER®, результати якого свідчать про переваги у споживанні відомих цукерок без штучних ароматизаторів і барвників. Крім того, результати Глобального дослідження, проведеного Nielsen у 2014 році, показують, що для прийняття рішення про придбання харчових продуктів понад 60 \% американців не потребують ніякого стимулювання штучними барвниками або ароматизаторами. Враховуючи загальні тенденції ринку, Nestlé USA 3 кінця 2015 року видалила штучні ароматизатори і FDA-сертифіковані кольори, такі як Red 40 i Yellow 53 усіх своїх шоколадних цукерок і $з$ цього часу понад 250 продуктів і 10 брендів, включаючи NESTLÉ® BUTTERFINGER ${ }^{\circledR}$, CRUNCH® i BABY RUTH®, не мають штучних ароматизаторів і сертифікованих барвників [11]. Збереження смаку і зовнішнього вигляду цих продуктів без використання штучних інгредієнтів виявилося великою технологічною проблемою і для втілення задуму з пошуку відповідних натуральних інгредієнтів Nestlé знадобилося майже п'ять років [12]. Світовий гігант у галузі харчових продуктів General Mills також взяв на себе зобов'язання по видаленню всіх штучних барвників i ароматизаторів зі своїх продуктів на основі злаків, але практично без помітних змін смаку і кольору, одночасно представивши на ринок нові продукти: безглютенове шоколадне печиво Pillsbury i протеїн Cheerios [13]. Після цих великих харчових компаній у 2016 році M\&M Mars Inc. також було заявлено про поетапну відмову від штучних барвників у своєму асортименті харчових продуктів протягом п'ятирічного періоду у зв’язку із загальною тенденцією щодо використання натуральних інгредієнтів [14].

32017 року значно змінилося ставлення споживачів і до деяких конкретних харчових продуктів. У 1960-х роках цукрова промисловість США фінансувала дослідження, які занижували ризики від вживання цукру і висували на перший план небезпеки жиру. Внутрішні документи галузевої групи під назвою Sugar Research Foundation показують, що було поставлено завдання спростувати загальні побоювання 3 приводу можливої ролі цукру в серцевих захворюваннях [15]. Більше 40 років вважалося, що джерелом проблем із зайвою вагою $є$ жир, в той час як шкода від споживання великої кількості цукру недооцінюваласья У 2016 році дослідники навели переконливі докази, які змінили ставлення суспільства до харчових жирів, а американське Управління з санітарного нагляду за якістю харчових продуктів і медикаментів (FDA) оголосило про необхідність змінити на упаковках товарів дані про добові норми споживання калорій, а також білків, жирів і вуглеводів [16]. Після таких наукових даних найбільший ритейлер Великобританії, Tesco, заборонив розташування солодощів і шоколаду біля своїх кас, враховуючи переважну підтримку цього кроку зі сторони клієнтів. Дослідження Tеsco показало, що 65 \% покупців хотіли, щоб кондитерські вироби були вилучені з території біля каси, що допоможе їм зробити більш здоровий вибір при здійсненні покупок, при цьому 67 \% зазначили необхідність такого кроку для обрання більш корисних варіантів для своїх дітей [17]. 
Дисбаланс між зниженням енерговитрат через відсутність фізичної активності і високою енергією в раціоні (надлишок калорій, чи то цукор, чи то крохмаль, чи то жир) є основним фактором, що визначає епідемію ожиріння. Серцево-судинні захворювання, які є основними причинами смерті в усьому світі, значною мірою обумовлені незбалансованим харчуванням і відсутністю фізичного навантаження. Вже існує загальне розуміння, що не всі жири однакові і наукова складність цього питання не має ставати на заваді споживачам при виборі харчових продуктів [18]. У травні 2004 року П'ятдесят сьома сесія Всесвітньої асамблеї охорони здоров’я прийняла Глобальну стратегію Всесвітньої організації охорони здоров'я по харчуванню, фізичній активності і здоров'ю, яка була розроблена на основі цілого ряду широких консультацій з усіма зацікавленими партнерами у відповідь на запит, що поступив від державчленів на сесії Всесвітньої асамблеї охорони здоров'я 2002 року (резолюція WHA55.23). Що стосується раціону харчування, то основою для дій стратегія передбачає обмеження надходження енергії за рахунок вживання жирів і перехід від споживання насичених жирів і трансжирних кислот на ненасичені жири, підвищення споживання фруктів і інших рослинних продуктів, у тому числі овочів, немеленого зерна i горіхів [19].

Відмова споживачів від цукру, насичених жирів, солі і штучних інгредієнтів змінює ринок харчових продуктів такими швидкими темпами, ніж будь-коли до цього. Окрім печива, кондитерських виробів і чіпсів до поняття снеків тепер належать продукти з використанням йогуртів, енергетичні батончики, горіхові снеки тощо. Сегмент «здорових» снеків став одним з найбільш швидкозростаючих у світі і якщо роздрібні продажі традиційних снеків за 2015 рік виросли на $5 \%$ і досягли \$ 505 млрд, то продажі «здорових» снеків з 2011 ро 2015 рокк збільшились на 4 \% і ще на 7 \% за 2015, досягнувши \$ 140 млрд. Одним із конкурентів традиційних виробників снеків, компаній General Mills i Kellogg, став стартап Kind, частка якого на ринку батончиків вже становить 12 \% (частка на ринку у 2011 році дорівнювала практично нулю), а за даними Bernstein частка Kellogg за той же період зменшилася з 30 до 20 \%. І це незважаючи на те, що батончики Kind коштують втричі дорожче за аналогічний продукт Kellogg, але, за словами засновника компанії, добре продаються завдяки своєму смаку, низькому вмісту цукру і високому вмісту горіхів, фруктів і злаків [20]. За даними опитування дослідницької фірми Hartman Group, 30 \% молодих людей вважають органічні інгредієнти надзвичайно важливими (порівняно з 22 \% старшого покоління) i надають перевагу здоровим напівфабрикатам, готовим стравам у продуктовому магазині, а також наборам страв [21].

За останні роки також зросла потреба в оцінці вмісту мікроелементів у харчових продуктах, тому що неякісне харчування призводить до збільшення кількості хвороб. Недостатній рівень мікроелементів у харчових продуктах зазвичай характерний для країн з низьким доходом і малозабезпечених верств населення, проте ця нестача також має місце в індустріально розвинених країнах. Враховуючи глобальність проблеми, Всесвітня організація охорони здоров'я вбачає за необхідне розробити і впровадити відповідні програми збагачення харчових продуктів [22]. Потенційні споживачі значну увагу приділяють також вмісту вітамінів у продукті, намагаючись таким чином компенсувати помилки у харчуванні. У 2011 році видання Јournal of Nutrition опублікувало дані про те, що значна частка вітамінів A, B6, B12, C та D, а також тіамін, рибофлавін і залізо, потрапляють в організм людини у складі штучно виготовлених вітамінів і (або) продуктів, збагачених вітамінами. При втраті синтетичних вітамінів та збагачених вітамінами продуктів і харчових добавок $100 \%$ американців не зможуть задовольнити очікувану середню потребу у вітаміні D; 74 \% - у вітаміні A; 46 \% - у вітаміні C; 93 \% - у вітаміні Е; $51 \%$ - у тіаміні; $22 \%$ - у вітаміні В6 і $88 \%$ - у фолієвій кислоті. Автори роблять висновок, що незважаючи на весь добробут і скрупульозне ставлення до вибору продуктів, тільки завдяки синтетичним вітамінам сучасні американці не піддаються загрозі серйозних авітамінозів [23]. Разом із тим необхідно зазначити, що вчені все ще повністю не розібралися в усіх тонкощах впливу вітамінів на організм людини, що надзвичайно ускладнює рекомендації стосовно здорового харчування. Неурядова комісія з харчування та харчових продуктів при Національній академії наук США у 2003 році визнала, що наукові дослідження так і не визначили оптимальну кількість того чи іншого продукту залежно від віку або статевої приналежності кожної людини і, відповідно, це не може бути використано в сучасних рекомендаціях 3 харчування, при цьому деякі отримані позитивні ефекти можуть бути співвіднесені з абсолютно різними кількостями певного спожитого продукту [24].

Аналіз глобального ринку харчування свідчить, що людство почало споживати більше снеків середньостатистична людина вгамовує голод закусками більше п'яти разів на день. За даними дослідницької компанії в області харчових продуктів Innova Market Insights попит на снеки з фруктовою основою (на зразок поживних батончиків з натуральної сировини) є найбільш динамічним і 2012 до 2017 року їх частка збільшилася більш ніж у два рази - 8 до $18 \%$. Міжнародне видання Natural Products Insider стверджує, що, починаючи з 2010 року загальною домінуючою тенденцією в сфері харчових продуктів $€$ насичення глобального ринку і припинення його зростання (навіть спад у деяких регіонах) в натуральному вираженні при незначному зростанні в грошовому, але при цьому сегмент енергетичних батончиків і снеків на основі натуральних фруктів демонструє впевнене зростання як в натуральному, так і в грошовому 
еквіваленті. Це зростання обумовлено змінами по відношенню до потреб споживачів, створенню продуктів, постійно готових до вживання, які зручно мати при собі, щоб швидко відновити сили. Згідно 3 дослідженнями міжнародної агропромислової корпорації Archer Daniels Midland, смакові відчуття i оригінальні поєднання компонентів залишаються важливим критерієм вибору для 51 \% покупців снеків, але разом із тим споживачі почали більше уваги приділяти «здоровим» інгредієнтам, 3 яких створено снеки. Споживчий вибір все більше обумовлює скорочення використання або повну відсутність консервантів та барвників, вміст виключно натуральних компонентів, таких як горіхи, овочі, фрукти тощо [25].

Харчування є важливою частиною і для багатьох видів аматорських спортивних тренувань, зростаюча популярність яких давно стала світовою тенденцією на тлі загального збільшення кількості людей, що прагнуть вести активний і здоровий спосіб життя. Цей тренд не оминув і Україну: за даними інформаційноаналітичної платформи FitnessConnectUA, споживачами фітнес-послуг сьогодні є понад 1 млн осіб, або $2, \%$ населення України. Разом з тим, Україна є яскравим прикладом країни, в якій внутрішнє виробництво спортивного харчування, незважаючи на досить значну сировинну і технологічну базу, активно не розвивалося [26].

Враховуючи зростаючий попит, розробники фруктових батончиків для функціонального харчування 3 овочевими, злаковими та горіховими добавками, пропонують застосовувати декілька рецептур сировини на 100 кг готової продукції, кг:

- 1 варіант) обліпиха 3 масовою часткою сухих речовини (СР) в сировині $8 \%-10$; калина із СР в сировині $8 \%$ - 10; яблука із СР в сировині $10 \%$ - 20; топінамбур із СР в сировині $22 \%$ або ревінь із СР в сировині $8 \%$ - 10; цукор СР в сировині 99,9\% - 50;

- 2 варіант) обліпиха із СР в сировині $10 \%$ - 10; горобина із СР в сировині $15 \%$ - 10; яблука із СР в сировині $10 \%$ - 20; ядра насіння соняшника або гарбуза із СР в сировині 78,0 \% - 10; цукор СР в сировині $99,0 \%-50$

- 3 варіант) калина із СР в сировині $10 \%$ - 10; горобина із СР в сировині $15 \%$ - 10; яблука із СР в сировині $10 \%$ - 20; арахіс або горіхи із СР в сировині 87,0 \% - 10; цукор із СР в сировині 99,0 \% - 50 [27].

Інші дослідники для позитивного впливу на силовий індекс, швидкісно-силову витривалість та загальну фізичну працездатність пропонують споживачам фітнес-батончики, які містять бурштинову кислоту $(0,8 \ldots 1,2 \%)$, L-карнітин $(0,4 \ldots 0,8 \%)$, пластівці гречані $(12,0 \ldots 15,0 \%)$, патоку $(16,0 \ldots 20,0 \%)$, сухий концентрат сироваткового білка молока $(18,0 \ldots 20,0 \%)$, макуху ядра кедрового горіха $(22,0 \ldots 24,0 \%)$, гемоглобін порошкоподібний $(4,0 \ldots 6,0 \%)$, порошок з гранатових кісточок $(6,0 \ldots 8,0 \%)$, цукор як солодкий компонент (залишок, \%), кислоту лимонну $(0,02 \ldots 0,05 \%)$, гліцерин $(0,3 \ldots 0,7 \%)[28]$.

Проведене маркетингове дослідження дає можливість оцінити відповідність сприйняття загальних світових тенденцій споживачами енергетичних батончиків в Україні. За даними анкетування, респонденти за віком розподілилися таким чином: найбільш широко представлена вікова група від 18 до 29 років - 48,1 \%, на другому місці група від 30 до 39 років - 29,2 \%, далі група від 40 до 49 років - 15,4 \%, і останньою $\epsilon$ вікова група понад 50 років - 7,3 \%. Дані свідчать про те, що більшість респондентів приділяють значну увагу вмісту натуральної сировини та поживних речовин (рис.1-2).
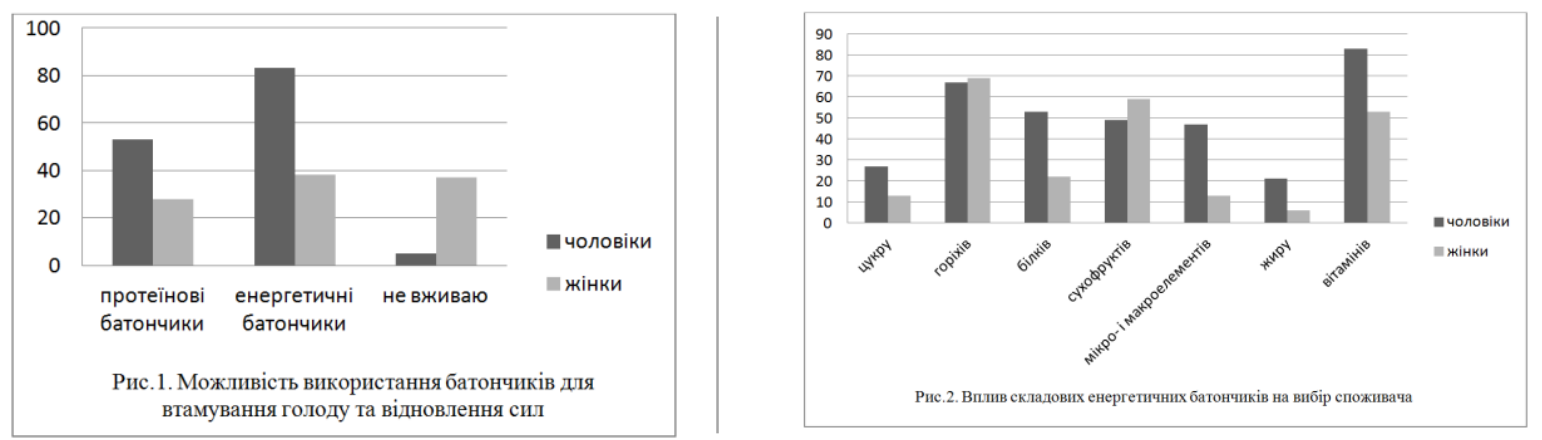

В цілому для отримання готового продукту пропонуюється використовувати як технологію 3 термічним обробленням рослинної сировини, так і без такого оброблення. 3 точки зору технологічних операцій, виробництво фруктово-ягідних снеків з термічним обробленням сировини містить: підготовку сировини; приготування суміші фруктово-ягідної сировини з цукрозамінниками; приготування фруктовоягідної маси у варильному котлі, додавання пектинової суміші у котел і при уварюванні отримання маси 3 сухими речовинами $65 . .68$ \%; викладання готової маси тонким шаром на поверхні листа та висушування у сушильній шафі; попереднє охолодження до температури $40 \ldots 45{ }^{\circ} \mathrm{C}$ і продовження висушування при цій температурі впродовж 4 годин; остаточне охолодження до температури $25 \ldots 30{ }^{\circ} \mathrm{C}$, після чого пласти 
готового продукту з вологістю $20 . .22$ \% розрізають дисковими ножами на зручний для споживання формат у вигляді смужок або батончиків і досушують до вологості 15..17 \% [29]. При виробництві енергетичних батончиків із рослинної сировини та смакоароматичних добавок, коли використовують лише суміш рослинної сировини (горіхи, фініки, сухофрукти), що не пройшла термічного оброблення, вихідні компоненти беруть у певному співвідношенні: горіхи - 4 частини; фініки - 1,5 частини; сухофрукти - 0,5 частини; морська сіль - 0,02 частини. Після отримання рецептурної суміші, формують смуги з подальшим нарізанням їх для одержання кінцевих розмірів батончика. Отримані батончики охолоджують при температурі $18 . .23{ }^{\circ} \mathrm{C}$ протягом 1 години [30]. В цілому є декілька популярних видів сировини, що може використовуватись під час виготовлення енергетичних батончиків, адже наявність у складі горіхів та сухофруктів сприяє нормалізації функціонування нервової системи, накопиченню енергії в клітинах, підтриманню імунітету і здоров'я серцево-судинної системи, допомагає швидше відновлювати сили [31]. Разом із тим, використання для виробництва сировини і напівфабрикатів, що не пройшли відповідного термічного оброблення, вимагає ретельного вивчення кожного етапу технологічного процесу на наявність ризиків безпеки харчового продукту, адже у готовому виробі не допускається вміст патогенних мікроорганізмів та забрудників паразитарних захворювань і їх токсинів, що можуть викликати інфекційні хвороби або становити небезпеку для здоров'я людини. Кожен продукт має свій особливий тип мікробіоценозу, до складу якого входять мікроорганізми, що захищають продукт від інших видів мікробіологічного забруднення, але щороку фіксується поява нових патогенних мікроорганізмів або ж таких, що раніше не зустрічалися в харчових продуктах. Останні тенденції до збільшення кількості захворювань внаслідок вживання заражених харчових продуктів значною мірою пов'язані із зміною харчових звичок людей і недостатньою увагою до показників мікробіологічного складу продукту.

Розрізняють два типи мікробіологічних критеріїв для встановлення показників безпечності харчових продуктів [32]:

- критерії безпеки харчових продуктів і кормів, що визначають прийнятність продукту або партії харчових продуктів, які продаються на ринку. До цих критеріїв належать патогенні мікроорганізми, а саме Listeria monocytogenes та бактерії роду Salmonella;

- гігієнічні критерії технологічного процесу, що свідчать про прийнятне функціонування виробничого процесу. Такий показник встановлює орієнтовне гранично допустиме значення зараженості, вище за яке потрібні коригувальні дії для підтримання рівня гігієни технологічного процесу відповідно до харчового законодавства. Дані критерії представлені індикаторними мікроорганізмами, до яких належать мезофільні аеробні та факультативно анаеробні мікроорганізми, а також представники сімейства Enterobacteriaceae.

Під час виробництва енергетичних батончиків використовується сировина, що не проходить попереднього термічного оброблення і яка не буде піддаватись такому обробленню під час технологічних операцій, тому для покращення мікробіологічних показників харчового продукту необхідно додати до його складу рослинні інгредієнти 3 антимікробною дією. Імбир має усі необхідні показники для використання як додаткової сировини при виробництві енергетичних батончиків, але ефірні олії і феноли, якими багата ця пряність, подразнюють слизову оболонку, що може привести до загострень хвороб шлунково-кишкового тракту. Більш доцільно додавати до складу харчового продукту журавлину, яка багата органічними кислотами, флавоноїдами, мікроелементами і вітамінами та відома своїми протизапальними, інсектицидними і протимікробними властивостями. Принципову схему процесу виробництва батончиків з натуральної сировини представлено на рисунку 3.

Враховуючи усі компоненти, що використовуються при виробництві енергетичного батончика, його харчова цінність буде такою: калорійність - 142,8 кКал; вміст білків - 3,8 г; жирів - 8,2 г; вуглеводів - 13,6 г; органічних кислот - 0,3 г; харчових волокон - 2,7 г; вітаміну А - 46,8 мкг; b-car - 0,282 мг; вітаміну В1 - 0,08 мг; вітаміну В2 - 0,098 мг; вітаміну В4 (холін) - 11,04 мг; вітаміну В5 - 0,187 мг; вітаміну В6 - 0,072 мг; вітаміну В9 - 13,92 мкг; вітаміну С - 2,66 мг; вітаміну Е - 2,886 мг; вітаміну Н - 2,488 мкг; вітаміну К - 4,5 мкг; вітаміну PP - 1,4346 мг; калію (K) - 330 мг; кальцію (Ca) - 48 мг; кремнію (Si) - 11,2 мг; магнію $(\mathrm{Mg})$ - 53,68 мг; натрію (Na) - 8,08 мг; сірки (S) - 29,26 мг; фосфору $(\mathrm{Ph})-76,5$ мг; хлору (Cl) - 4,09 мг; алюмінію (Al) - 126 мкг; бору (B) - 43,8 мкг; заліза (Fe) - 1,367 мг; йоду (I) - 1,42 мкг; кобальту (Cо) - 2,32 мкг; літію (Li) - 3,16 мкг; марганцю (Mn) - 0,3053 мг; міді $(\mathrm{Cu})$ - 238,05 мкг; молібдену (Мо) - 6,928 мкг; нікелю (Ni) - 19,416 мкг; селену (Se) - 1,52 мкг; фтору (F) - 33,15 мкг; хрому (Cr) - 5,92 мкг; цинку (Zn) 0,6867 мг. Таким чином, при виробництві таких батончиків в закладах готельно-ресторанного господарства буде отримано цілком безпечний продукт харчування із більш збалансованим складом основних поживних речовин, значною кількістю мікроелементів, вітамінів і біологічно активних речовин антистресової та імуностимулюючої дії. 


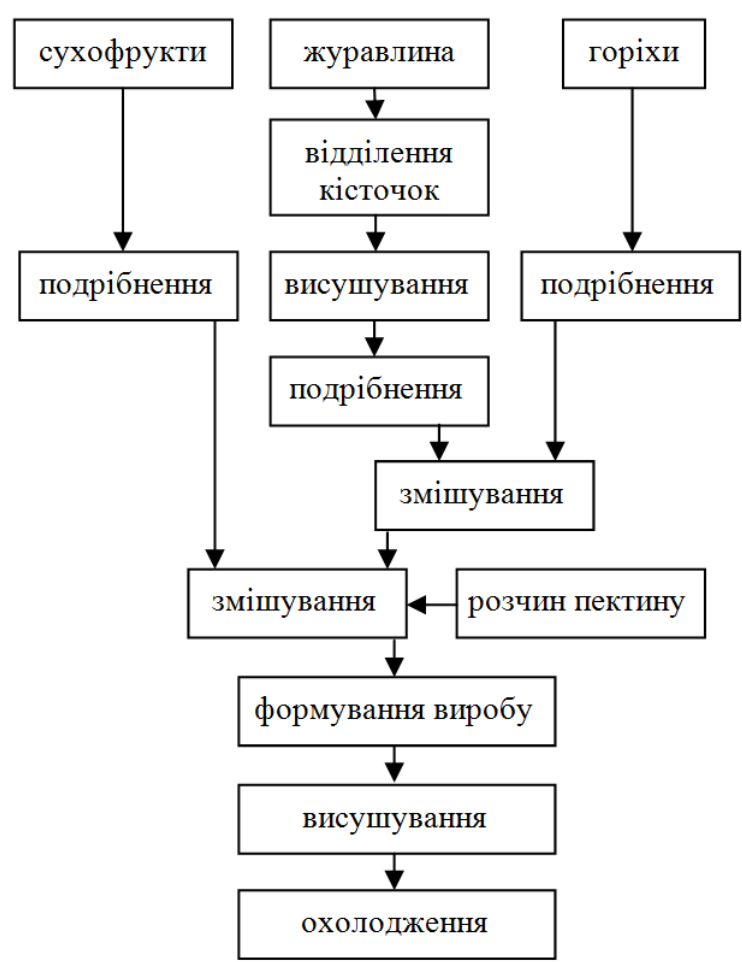

Рис. 3. Принцииова схема виробництва енергетичних батончиків з натуральної сировини

Висновки. Сучасний стиль життя людей значно прискорив зміну ринку харчових продуктів, основними вимогами до яких стає загальнодоступність, швидке отримання достатньої кількості енергії для відновлення фізичних сил та приведення в тонус мозкової діяльності. Для задоволення цих потреб запропоновано виробництво у готельно-ресторанних господарствах енергетичних батончиків, що мають високу біологічну цінність та гармонійні органолептичні показники. 3 технологічної точки зору для досягнення результатів щодо максимального унеможливлення мікробіолочного забруднення під час виробництва доцільно застосовувати системи управління безпекою (НACCP) і якістю (ISO 9001).

\section{Список використаної літератури:}

1. Кошова В.М. Енергетичні напої з новими смаковими добавками / В.М. Кошова, І.О. Черняк // Харчова промисловість. - 2011. - № 10-11. - С. 46-49.

2. Артемова Е.Н. Научные основы пенообразования и эмульгирования в технологии пищевых продуктов с растительными добавками : дис. ... д.т.н. : спец. 05.18.16 / Е.Н. Артемова ; Российская экономическая академия им. Г.В. Плеханова. - С.-Пб., 1999. -372 с.

3. Згурський A.B. Перерозподіл пектинових речовин в овочевій сировині при виробництві морозива / A.B. Згурський, Г.С. Полішук, І.О. Крапивницька // Харчова промисловість. - 2010-2011. - № 10-11. - С. 50-55.

4. Павлюк Р.Ю. Новые фитодобавки и их использование в продуктах питания / Р.Ю. Павлюк, А.И. Черевко, А.И. Украинеи. - Харьков-Киев : ХГУПТ, 2003. - 286 с.

5. Chung Hua Hsueh Tsa Vitamine Physiologie, Pathophisiologie, Therapie / Chung Hua Hsueh Tsa // Inhibitory effect of selenium on conplement activation and its clinical significance. - 1993. - № 73. - Pp. 643-699.

6. Шатнюк Л.Н. Соки и напитки как источник витаминов в питании человека / Л.Н. Шатнюк, В.Б. Спиричев // Вопросы питания. - 1999. - Вып. 68. - № 2. - С. 5-11.

7. UK energy bar sales triple and set to rise [Електронний pecypc]. - Режим доступу : https://www.nutraingredients.com/Article/2015/02/24/UK-energy-bar-sales-triple-and-set-torise?utm_source=copyright\&utm_medium $=$ OnSite\&utm_campaign=copyright.

8. An unusual type of protein snack is after the hearts and wallets of average Americans [Електронний ресурс]. Режим доступу : https://www.businessinsider.com/the-rise-of-the-meat-protein-bar-2016-4.

9. Протеиновые снеки из мяса заменят традиционные шоколадные батончики [Електронний ресурс]. - Режим доступу : https://rueconomics.ru/170852-proteinovye-sneki-iz-myasa-zamenyat-tradicionnye-shokoladnyebatonchiki.

10. Глобальная стратегия ВОЗ в области безопасности пищевых продуктов [Електронний ресурс]. - Режим доступу : https://apps.who.int/iris/bitstream/handle/10665/42559/9241545747_rus.pdf?sequence=4.

11. Nestlé USA Commits to Removing Artificial Flavors and FDA-Certified Colors from All Nestlé Chocolate Candy by the End of 2015 [Електронний ресурс]. - Режим доступу : 
https://www.nestleusa.com/media/pressreleases/nestl\%C3\%A9-usa-commits-to-removing-artificial-flavors-andfda-certified-colors-from-all-nestl\%C3\% A9-chocolate-candy-by-the-end-of-20.

12. No artificial ingredients: what it takes to get synthetics out of Coke and Cheetos [Електронний ресурс]. - Режим доступу : https://www.theguardian.com/sustainable-business/2015/jun/23/artificial-ingredients-synthetics-cokecheetos-coca-cola-nestle-kraft-hershey.

13. General Mills removing fake colors and flavors from cereals - will your kids care? [Електронний ресурс]. - Режим доступу : https://www.latimes.com/food/dailydish/la-dd-general-mills-artificial-colors-flavors-cereals-20150622story.html.

14. Mars to Phase Out Artificial Colors in M\&M's, Other Foods [Електронний pecypc]. - Режим доступу : https://www.wsj.com/articles/mars-to-phase-out-artificial-colors-in-m-ms-other-foods-1454711099.

15. Sugar Industry and Coronary Heart Disease Research A Historical Analysis of Internal Industry Documents [Електронний ресурс]. - Режим доступу : https://jamanetwork.com/journals/jamainternalmedicine/articleabstract/2548255.

16. 50 Years Ago, Sugar Industry Quietly Paid Scientists To Point Blame At Fat [Електронний ресурс]. - Режим доступу : https://www.npr.org/sections/thetwo-way/2016/09/13/493739074/50-years-ago-sugar-industry-quietlypaid-scientists-to-point-blame-at-fat.

17. Tesco bans sweets from checkouts in all stores [Електронний ресурc]. - Режим доступу : https://www.theguardian.com/business/2014/may/22/tesco-bans-sweets-from-checkouts-all-stores.

18. Diet, nutrition and the prevention of chronic diseases Report of the joint WHO/FAO expert consultation [Електронний pecypc]. - Режим доступу : https://www.who.int/dietphysicalactivity/publications/trs916/summary/en/.

19. Глобальная стратегия по питанию, физической активности и здоровью / ВОЗ. - Женева, 2004. -18 с.

20. Крупнейшие компании вступают в битву за рынок «здоровых» снеков [Електронний ресурс]. - Режим доступу : https://www.vedomosti.ru/business/articles/2017/01/30/675439-krupneishie-bitvu-zdorovih-snekov.

21. Millennial Consumers: A Barometer for the Future of Food Culture [Електронний ресурс]. - Режим доступу : https://www.hartman-group.com/newsletters/920018184/millennial-consumers-a-barometer-for-the-future-of-foodculture

22. Guidelines on food fortification with micronutrients [Електронний ресурс]. - Режим доступу : https://apps.who.int/iris/bitstream/handle/10665/43412/9241594012_eng.pdf?sequence=1.

23. Foods, Fortificants and Supplements: Where Do Americans Get Their Nutrients? / V.L. Fulgoni, D.R. Keast, R.L. Bailey, J.Dwyer // Journal of Nutrition. - 2011. - Vol. 141, № 10. - 1847 p.

24. Dietary Reference Intakes: Guiding Principles for Nutrition Labeling and Fortification / Committee on Use of Dietary Reference Intakes in Nutrition Labeling, Food and Nutrition Board. - Washington, DC : The National Academies Press, 2003. $-74 \mathrm{p}$.

25. Доля батончиков на натуральной основе увеличилась в категории снэков до $18 \%$ [Електронний ресурс]. Режим доступу : https://trademaster.ua/news/17328.

26. СПОРТ \& ПИТАНИЕ: как выглядит внутренняя кухня рынка спортивного питания в мире и Украине [Електронний ресурс]. - Режим доступу : https://project.liga.net/projects/sports_nutrition/.

27. Патент № 2493720 РФ. Способ производства фруктовых батончиков для функционального питания с овощными, злаковыми и ореховыми добавками / В.В. Винницкая, Е.И. Попова, А.Ю. Кориунов, С.С. Комаров ; опубл. 27.09.13 [Електронний ресурс]. - Режим доступу : http://www.freepatent.ru/patents/2493720.

28. Патент № 2583083 РФ. Композиция для производства фитнес-батончиков / Н.А. Тарасенко, В.Ю. Архипов ; опубл. 10.05.16 [Електронний ресурс]. - Режим доступу : http://www.findpatent.ru/patent/258/2583083.html.

29. Патент № 2560950 РФ. Фруктово-ягодные снеки и способы их производства / М.А. Минаева; опубл. 20.08.15 [Електронний ресурс]. - Режим доступу : http://www.findpatent.ru/patent/256/2560950.html.

30. Патент на корисну модель № 78251 Україна, МПК A23G 3/00 (2013.01). Спосіб виробництва енергетичних батончиків / М.К. Войтюк (заявник). - № u 201211083 ; заяв. 24.09.12 ; опубл. 11.03.13, Бюл. № 5.

31. Тарасюк Г.М. Управління технологічними процесами виробництва енергетичних батончиків з натуральної сировини в закладах готельно-ресторанного господарства / Г.М. Тарасюк, А.О. Чагайда, О.В. Мілінчук // Вісник ЖДТУ. Серія : Економічні науки. - 2019. - № 1 (87). - С. 150-155.

32. Регламент Комісії ЄС № 2073/2005 від 15 листопада 2005 року щодо мікробіологічних критеріїв для харчових продуктів / Комісія ЄС / Верховна Рада України [Електронний ресурс]. - Режим доступу : https://zakon.rada.gov.ua/laws/show/994_a87.

\section{References:}

1. Koshova, V.M. and Chernjak, I.O. (2011), «Energetychni napoi’ z novymy smakovymy dobavkamy», Harchova promyslovist', № 10-11, pp. 46-49.

2. Artemova, E.N. (1999), Nauchnye osnovy penoobrazovanija i jemul'girovanija v tehnologii pishhevyh produktov $s$ rastitel'nymi dobavkami, Diss. of D.t.n., spec. 05.18.16, Rossijskaja jekonomicheskaja akademija im. G.V. Plehanova, S.-Pb., 372 p.

3. Zgurs'kyj, A.V., Polishhuk, G.Je. and Krapyvnyc'ka, I.O. (2010-2011), «Pererozpodil pektynovyh rechovyn v ovochevij syrovyni pry vyrobnyctvi morozyva», Harchova promyslovist', No. 10-11, pp. 50-55.

4. Pavljuk, R.Ju., Cherevko, A.I. and Ukrainec, A.I. (2003), Novye fitodobavki i ih ispol'zovanie v produktah pitanija, HGUPT, Har'kov, Kiev, 286 p.

5. Chung Hua Hsueh, Tsa (1993), «Vitamine Physiologie, Pathophisiologie, Therapie», Inhibitory effect of selenium on conplement activation and its clinical significance, No. 73, pp. 643-699. 
6. Shatnjuk, L.N. and Spirichev, V.B. (1999), «Soki i napitki kak istochnik vitaminov v pitanii cheloveka», Voprosy pitanija, Vol. 68, No. 2, pp. 5-11.

7. www.nutraingredients.com (2015), «UK energy bar sales triple and set to rise», [Online], available at: https://www.nutraingredients.com/Article/2015/02/24/UK-energy-bar-sales-triple-and-set-torise?utm_source=copyright\&utm_medium $=$ OnSite\&utm_campaign=copyright

8. www.businessinsider.com (2016), «An unusual type of protein snack is after the hearts and wallets of average Americans», [Online], available at: https://www.businessinsider.com/the-rise-of-the-meat-protein-bar-2016-4

9. «Proteinovye sneki iz mjasa zamenjat tradicionnye shokoladnye batonchiki», [Online], available at: https://rueconomics.ru/170852-proteinovye-sneki-iz-myasa-zamenyat-tradicionnye-shokoladnye-batonchiki

10. «Global'naja strategija VOZ v oblasti bezopasnosti pishhevyh produktov», [Online], available at: https://apps.who.int/iris/bitstream/handle/10665/42559/9241545747_rus.pdf?sequence=4

11. www.nestleusa.com (2015), «Nestlé USA Commits to Removing Artificial Flavors and FDA-Certified Colors from All Nestlé Chocolate Candy by the End of 2015», [Online], available at: https://www.nestleusa.com/media/pressreleases/nest1\%C3\%A9-usa-commits-to-removing-artificial-flavors-andfda-certified-colors-from-all-nestl\%C3\%A9-chocolate-candy-by-the-end-of-20

12. www.theguardian.com (2015), «No artificial ingredients: what it takes to get synthetics out of Coke and Cheetos», [Online], available at: https://www.theguardian.com/sustainable-business/2015/jun/23/artificial-ingredientssynthetics-coke-cheetos-coca-cola-nestle-kraft-hershey

13. www.latimes.com (2015), «General Mills removing fake colors and flavors from cereals - will your kids care?», [Online], available at: https://www.latimes.com/food/dailydish/la-dd-general-mills-artificial-colors-flavors-cereals20150622-story.html

14. www.wsj.com, «Mars to Phase Out Artificial Colors in M\&M's, Other Foods», [Online], available at: https://www.wsj.com/articles/mars-to-phase-out-artificial-colors-in-m-ms-other-foods-1454711099

15. «Sugar Industry and Coronary Heart Disease Research A Historical Analysis of Internal Industry Documents», [Online], available at: https://jamanetwork.com/journals/jamainternalmedicine/article-abstract/2548255

16. www.npr.org (2016), «50 Years Ago, Sugar Industry Quietly Paid Scientists To Point Blame At Fat», [Online], available at: https://www.npr.org/sections/thetwo-way/2016/09/13/493739074/50-years-ago-sugar-industry-quietlypaid-scientists-to-point-blame-at-fat

17. www.theguardian.com (2014), «Tesco bans sweets from checkouts in all stores», [Online], available at: https://www.theguardian.com/business/2014/may/22/tesco-bans-sweets-from-checkouts-all-stores

18. www.who.int, «Diet, nutrition and the prevention of chronic diseases Report of the joint WHO/FAO expert consultation», [Online], available at: https://www.who.int/dietphysicalactivity/publications/trs916/summary/en/

19. Vsemirnaja organizacija zdravoohranenija (2004), Global'naja strategija po pitaniju, fizicheskoj aktivnosti $i$ zdorov'ju, Zheneva, $18 \mathrm{p}$.

20. www.vedomosti.ru (2017), «Krupnejshie kompanii vstupajut v bitvu za rynok «zdorovyh» snekov», [Online], available at: https://www.vedomosti.ru/business/articles/2017/01/30/675439-krupneishie-bitvu-zdorovih-snekov

21. www.hartman-group.com, «Millennial Consumers: A Barometer for the Future of Food Culture», [Online], available at: https://www.hartman-group.com/newsletters/920018184/millennial-consumers-a-barometer-for-the-future-offood-culture

22. «Guidelines on food fortification with micronutrients», [Online], available at: https://apps.who.int/iris/bitstream/handle/10665/43412/9241594012_eng.pdf?sequence=1

23. Fulgoni, V.L., Keast, D.R., Bailey, R.L. and Dwyer, J. (2011), «Foods, Fortificants and Supplements: Where Do Americans Get Their Nutrients?», Journal of Nutrition, Vol. 141, No. 10, 1847 p.

24. Committee on Use of Dietary Reference Intakes in Nutrition Labeling, Food and Nutrition Board (2003), Dietary Reference Intakes: Guiding Principles for Nutrition Labeling and Fortification, The National Academies Press, Washington, DC, $74 \mathrm{p}$.

25. «Dolja batonchikov na natural'noj osnove uvelichilas' v kategorii snjekov do $18 \%$ \%, [Online], available at: https://trademaster.ua/news/17328

26. «SPORT \& PITANIE: kak vygljadit vnutrennjaja kuhnja rynka sportivnogo pitanija v mire i Ukraine», [Online], available at: https://project.liga.net/projects/sports_nutrition/

27. Vinnickaja, V.V., Popova, E.I., Korshunov, A.Ju. and Komarov, S.S. (2013), Sposob proizvodstva fruktovyh batonchikov dlja funkcional'nogo pitanija s ovoshhnymi, zlakovymi i orehovymi dobavkami [Method for the production of fruit bars for functional nutrition with vegetable, cereal and nut additives], Rossijskaja Federacija, opubl. ot 27 sentjabrja, Pat. № 2493720, [Online], available at: http://www.freepatent.ru/patents/2493720

28. Tarasenko, N.A. and Arhipov, V.Ju. (2016), Kompozicija dlja proizvodstva fitnes-batonchikov [Composition for longer fitness-batonchikov production], Rossijskaja Federacija, opubl. ot 10 maja, Pat. № 2583083, [Online], available at: http://www.findpatent.ru/patent/258/2583083.html

29. Minaeva, M.A. (2015), Fruktovo-jagodnye sneki i sposoby ih proizvodstva [Fruit and berry snacks and methods for their production], Rossijskaja Federacija, opubl. ot 20 avgusta, Pat. № 2560950, [Online], available at: http://www.findpatent.ru/patent/256/2560950.html

30. Vojtjuk, M.K. (2012-2013), Sposib vyrobnyctva energetychnyh batonchykiv [Sposib vyrobnyctva energetychnyh batonchykiv] MPK A23G 3/00, Patent na vynahid, Ukrai’na, zajav. vid 24 veresnja, opubl. vid 11.03.13, Bjul. № 5, Pat. № 78251, № u 201211083.

31. Tarasjuk, G.M., Chagajda, A.O. and Milinchuk, O.V. (2019), «Upravlinnja tehnologichnymy procesamy vyrobnyctva energetychnyh batonchykiv z natural'noi' syrovyny v zakladah gotel'no-restorannogo gospodarstva», Visnyk ZhDTU, Serija Ekonomichni nauky, No. 1 (87), pp. 150-155. 
32. Komisija JeS, Verhovna Rada Ukrai’ny (2005), «Reglament Komisii’ JeS № 2073/2005 vid 15 lystopada 2005 roku shhodo mikrobiologichnyh kryterii'v dlja harchovyh produktiv», [Online], available at: https://zakon.rada.gov.ua/laws/show/994_a87

Тарасюк Галина Миколаївна - доктор економічних наук, професор, декан факультету економіки та менеджменту Державного університету «Житомирська політехніка».

Наукові інтереси:

- проблеми теорії та практики планування діяльності суб'єктів господарювання;

- управління проектами;

- проблеми розвитку туризму та готельно-ресторанного бізнесу.

E-mail: galinatar@ukr.net.

Чагайда Андрій Олегович - кандидат технічних наук, доцент кафедри менеджменту і туризму Державного університету «Житомирська політехніка».

Наукові інтереси:

- проблеми теорії та практики технології виробництва на підприємствах харчової промисловості;

- міні-технології на підприємствах готельно-ресторанного господарства.

E-mail: andrey11081968@ukr.net. 